\title{
Agronomic efficiency of Rhizobium strains from the Amazon region in common bean
}

\author{
Cláudia de Oliveira Gonçalves NOGUEIRA ${ }^{1,2}$, Dâmiany Pádua OLIVEIRA ${ }^{1}$, Paulo Ademar Avelar \\ FERREIRA ${ }^{1,3}$, João Paulo de Andrade Rezende PEREIRA ${ }^{1}$, Helson Mário Martins do VALE ${ }^{1,4}$, Messias José \\ Bastos de ANDRADE ${ }^{5}$, Fatima Maria de Souza MOREIRA ${ }^{1^{*}}$ \\ 1 Setor de Biologia, Microbiologia e Processos Biológicos, Departamento de Ciências do Solo, Universidade Federal de Lavras - UFLA, Caixa Postal 3037, Lavras, \\ MG 37200-000, Brazil. \\ 2 Centro Universitário de Formiga - UNIFOR, Formiga, MG, Brazil. \\ ${ }^{3}$ Departamento de Ciências do Solo, Universidade Federal de Santa Maria - UFSM, Campus Cachoeira do Sul, Cachoeira do Sul, RS, Brazil. \\ ${ }^{4}$ Departamento de Fitopatologia, Universidade de Brasilia - UNB, Brasília, DF, Brazil. \\ ${ }^{5}$ Departamento de Agricultura, Universidade Federal de Lavras - UFLA, Lavras, MG, Brazil. \\ * Corresponding author: fmoreira@dcs.ufla.br
}

\section{ABSTRACT}

To maximize the contribution of biological nitrogen fixation in common bean, it is necessary to use bacterial strains that are more adapted, competitive, and efficient in the symbiotic process. In this regard, the aim of this study was to evaluate the agronomic efficiency (AE) of three bacterial strains isolated from acid soils with high Al content from the Amazon region in an Argissolo Vermelho Distrófico típico soil (Typic Rhodustults - USDA Classification) from the municipality of Formiga, MG, Brazil. We compared their AE to that of the reference strain CIAT $899^{\mathrm{T}}$ and of two controls without inoculation (one without and another with $80 \mathrm{~kg} \mathrm{ha}^{-1}$ of N-urea). The results indicated that inoculation with the strains UFLA 02-100 and UFLA 02-127 provides grain yield equivalent to inoculation with the reference strain and to the control with mineral $\mathrm{N}$. Thus, both have potential for recommendation as inoculants for common bean.

KEYWORDS: Phaseolus vulgaris L., rhizobia, biological nitrogen fixation, seed inoculation

\section{Eficiência agronômica de estirpes de Rhizobium isoladas da Amazônia sobre o feijoeiro-comum}

\begin{abstract}
RESUMO
Para maximizar a contribuição da fixação biológica de nitrogênio no feijoeiro-comum é necessária a utilização de estirpes de bactérias mais adaptadas, competitivas e eficientes no processo simbiótico. Nesse sentido, objetivou-se avaliar, em um Argissolo Vermelho Distrófico típico do município de Formiga-MG, a eficiência agronômica (EA) de três estirpes isoladas de solos ácidos e com alto teor de $\mathrm{Al}$ da Amazônia e comparar suas EA à da estirpe referência CIAT $899^{\mathrm{T}}$ e à de dois controles sem inoculaçáo (um sem e outro com $80 \mathrm{~kg} \mathrm{ha}^{-1}$ of N-ureia). Os resultados indicaram que a inoculaçáo com as estirpes UFLA 02-100 e UFLA 02-127 propicia rendimento de grãos equivalente ao da estirpe referência e ao do controle com $\mathrm{N}$ mineral e que por isso, ambas têm potencial para ser recomendadas como inoculantes para o feijoeiro-comum.
\end{abstract}

PALAVRAS CHAVE: Phaseolus vulgaris L., rizóbio, fixação biológica de nitrogênio, inoculação na semente 
Common bean is a legume capable of biological nitrogen fixation (BNF) through symbiosis with bacteria that fix atmospheric N2, which are able to supply at least part of the nitrogen $(\mathrm{N})$ required by the plant for its development, leading to significant savings in the use of nitrogen fertilizers (Figueiredo et al. 2016; Oliveira et al. 2016; Soares et al. 2016). In spite of this ability, factors such as competition among the bacteria introduced and others already established in the soil, along with exposure to adverse environmental conditions such as high temperatures and soil acidity, can compromise the efficiency of inoculation, with reflections on the BNF of the crop (Rufini et al. 2011; Fonseca et al. 2013; Figueiredo et al. 2016; Oliveira et al. 2016). To maximize the contribution of BNF, above all in tropical soils where acidity conditions are more accentuated, it is necessary to use strains that are more adapted, competitive, and efficient in the infection process (Ferreira et al. 2009; 2012; Rufini et al. 2011; Fonseca et al. 2013). In this regard, the aim of this study was to evaluate the agronomic efficiency (AE) in the field of Rhizobium strains isolated from acid soils with high aluminum (Al) content from the Amazon region and compare their $\mathrm{AE}$ to that of the reference strain CIAT $899^{\mathrm{T}}$ and of two controls without inoculation, with and without $\mathrm{N}$ from urea.

The field experiment was carried out in the rainy crop season in an Argissolo Vermelho Distrofico tipico (Typic Rhodustults - USDA classification) of known fertility (Table 1) of the municipality of Formiga, State of Minas Gerais (20 $27^{\prime} 26.408^{\prime \prime}$ S, $\left.45^{\circ} 26^{\prime} 26.839^{\prime \prime} \mathrm{W}\right)$. The climate of the area is Cwa, humid subtropical, with mean monthly rainfall of $272 \mathrm{~mm}$ in the period in which the trial was carried out (rainfall more concentrated after sowing, in the first month of the trial, reaching a mean value of $300 \mathrm{~mm}$ in this period) and a mean temperature of $23^{\circ} \mathrm{C}$, according to the National Meteorology Institute (Instituto Nacional de Meteorologia). The experimental design was of randomized blocks with six replications and six treatments. The treatments involved the individual inoculation of strains UFLA 02-100, UFLA 02127, and UFLA 02-86, isolated from soils of the Amazonian state of Rondônia and selected for their efficiency in Leonard jars, in pots with soil, and under field conditions (Soares et al. 2006; Ferreira et al. 2009; 2012; Rufini et al. 2011); the strain CIAT $899^{\mathrm{T}}$, approved by the Brazilian Ministry of Agriculture, Livestock, and Food Supply (Ministério da Agricultura, Pecuária e Abastecimento - MAPA) for production of commercial inoculants for bean seeds; and two controls without inoculation, one with $80 \mathrm{~kg} \mathrm{ha}^{-1}$ of N-urea (half at sowing and the other half in topdressing at 20 days after emergence - DAE) and another without N-urea. The three strains of the bacteria with the UFLA code belong to the SBMPBS/UFLA (Biology, Microbiology, and Biological Processes Sector) collection of the Universidade Federal de Lavras. A more detailed description of the strains is shown in Table 2. The native rhizobial populations able to nodulate beans at the site were approximately $10^{3}$ colony-forming units (CFU) $\mathrm{g} \mathrm{soil}^{-1}$. These most probable numbers were determined as described by Rufini et al. (2011).

The inoculant was prepared with peat (sterilized in a autoclave), mixed at a ratio of 3:2 (w:w) with log phase cultures in a semi-solid 79 medium (Fred and Waksman 1928), according to the procedures described by Soares et al. (2006). The resulting material was applied at a ratio of $10 \mathrm{~g}$ per $\mathrm{kg}$ of seeds. Inoculant quality was monitored by counting the number of $\mathrm{CFU}$ and comparing it to the minimum legal number of viable cells, approximately $10^{9}$ Rhizobium cells

Table 1. Chemical characteristics of a soil sample collected in 0 to $20 \mathrm{~cm}$ in Formiga, Minas Gerais, Brazil.

\begin{tabular}{|c|c|c|c|c|c|c|c|c|c|c|c|}
\hline \multicolumn{12}{|c|}{ Characteristics } \\
\hline $\mathrm{pH}$ & $\mathrm{P}$ available & K & $\mathrm{Ca}$ & $\mathrm{Mg}$ & $\mathrm{Al}$ & SB & $t$ & $T$ & $\mathrm{~m}$ & V & OM \\
\hline$\left(\mathrm{H}_{2} \mathrm{O}\right)$ & $\mathrm{mg} \mathrm{dm} \mathrm{m}^{-3}$ & & & & cmolc $\mathrm{dm}^{-3}$ & & & & $\%$ & & dag $\mathrm{kg}^{-1}$ \\
\hline 5.6 & 6.5 & 160.0 & 2.8 & 1.5 & Undetected & 4.7 & 4.7 & 8.3 & 0.0 & 56.7 & 2.2 \\
\hline
\end{tabular}

Table 2. Origin, characteristics and identification of Rhizobium strains used as inoculants for the common bean (Phaseolus vulgaris L.) in the study.

\begin{tabular}{|c|c|c|c|c|c|c|c|c|}
\hline \multirow{2}{*}{ Strains } & \multirow{2}{*}{ *LUS/ Location } & \multicolumn{6}{|c|}{ Growth characteristics in 79 medium } & \multirow{2}{*}{ Identification } \\
\hline & & $\mathrm{GR}^{\mathrm{a}}$ & $C D^{b}$ & $\mathrm{GP}^{\mathrm{c}}$ & $\mathrm{pH}^{\mathrm{d}}$ & $\mathrm{Al}^{\mathrm{e}}$ & $\mathrm{CC}^{f}$ & \\
\hline UFLA 02-1009 & Agriculture, R0-Brasil & $\mathrm{F}$ & $>2$ & Low & Neutral & Yes & White & Rhizobium etli \\
\hline UFLA 02-869 & Agriculture, R0-Brasil & $\mathrm{F}$ & $>2$ & High & Neutral & Yes & White & R. etli bv. phaseoli \\
\hline UFLA 02-1279 & Agriculture, R0-Brasil & $\mathrm{F}$ & $>2$ & Medium & Neutral & Yes & White & R. leguminosarum bv. phaseoli \\
\hline CIAT 899' g & Colômbia & $\mathrm{F}$ & $>2$ & High & Acidic & Yes & Yellow & R. tropici \\
\hline
\end{tabular}

*LUS: Land use system from which the strain was isolated. $\mathrm{RO}=$ Rondônia state. Growth characteristics in 79 medium: ${ }^{\mathrm{a}} \mathrm{GR}$. Growth rate - F: Fast (3 days); ${ }^{\mathrm{b}} \mathrm{CD}$. Colony diameter; ${ }^{\mathrm{G}} \mathrm{GP}$ :

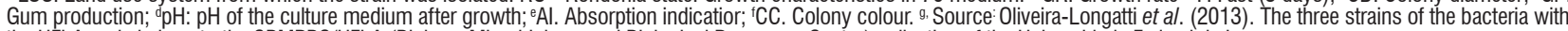
the UFLA code belong to the SBMPBS/UFLA (Biology, Microbiology, and Biological Processes Sector) collection of the Universidade Federal de Lavras. 
per gram of inoculant. The final concentration was about $10^{6}$ Rhizobium cells per seed.

The experimental plot consisted of twelve 6-m-long bean rows, with $0.5 \mathrm{~m}$ between rows. Two rows on each side of the plot were considered borders and the eight central rows were used for data collection. Soil tillage included plowing, harrowing, and demarcation of rows. The planting furrows of all plots were fertilized with $90 \mathrm{~kg} \mathrm{ha}^{-1}$ of $\mathrm{P}_{2} \mathrm{O}_{5}$ (triple superphosphate source) and $20 \mathrm{~kg} \mathrm{ha}^{-1}$ of $\mathrm{K}_{2} \mathrm{O}$ (potassium chloride source). Immediately after Rhizobium inoculation, manual sowing was carried out of the 'Pérola' cultivar of carioca bean, with 17 seeds per meter. Manual weeding was performed whenever necessary. Preventive disease control was performed with applications of triphenyltin hydroxide $\left(\mathrm{Mertin}^{\circledR} 400 \mathrm{~g} \mathrm{~L}^{-1}\right)$ at $25 \mathrm{DAE}$ and azoxystrobin (Amistar ${ }^{\circledR}$ $\left.50 \mathrm{~g} \mathrm{~kg}^{-1}\right)$ at $30 \mathrm{DAE}$, both at a spray volume of $400 \mathrm{~L} \mathrm{ha}^{-1}$. There was no need for pest control. The trial plot received supplementary irrigation by conventional sprinkler.

At the R6 stage of the bean cycle (flowering, $45 \mathrm{DAE}$ ), 10 plants were collected from each plot (rows 3 and 10) for assessments of number of nodules, nodule dry matter, and shoot dry matter. At the R9 stage (plant maturity), final stand (FS) and grain yield (GY) were determined (rows 4-9). The FS was obtained by counting the number of plants, which was expressed as number of plants per hectare. The GY was expressed in $\mathrm{kg} \mathrm{ha}^{-1}$ at $130 \mathrm{~g} \mathrm{~kg}^{-1}$ moisture.

The data were subjected to analysis of variance using the Sisvar 4.0 software (Ferreira 2011). To fulfill the assumptions of analysis of variance, the data of $\mathrm{NN}$ and $\mathrm{DMN}$ were first transformed in $(x+1)^{0.5}$. According to the official protocol for evaluation of the variability and agronomic efficiency of the plant stocks, inoculants, and technologies related to the BNF process in legumes (Brasil 2011), when there was a significant effect of cultivars or of inoculation treatments by the $F$ test $(p<0.05$ or $p<0.10)$, clustering of the mean values was performed by the Scott-Knott test at the same level of significance.
There was no significant variation in nodulation and shoot dry matter production of the inoculated and non-inoculated treatments, which did not differ from the controls that were fertilized or not fertilized with mineral N (Table 3), which has also been observed in other studies (Fonseca et al. 2013; Figueiredo et al. 2016; Oliveira et al. 2016). Fertilization with $40 \mathrm{~kg} \mathrm{ha}^{-1}$ of N-urea at planting did not affect nodulation because the low application rate was insufficient to suppress nodulation, as also indicated by Figueiredo et al. (2016). Another possible explanation for this occurrence is that high rainfall, in the order of $300 \mathrm{~mm}$, leached part of the mineral $\mathrm{N}$ and stimulated nodulation of the plant in response to the nutritional deficiency induced (Moreira and Siqueira 2006; Figueiredo et al. 2016). It is possible that this same moisture available in the soil during establishment of the crop was decisive so that no saline effect would be manifested on plant density with an increase in nitrogen fertilization (Table 3). For that reason, any difference in grain yield cannot be attributed to differences in FS.

Although the performance of the native population on nodulation and plant growth in this study was similar to that of the other treatments, its contribution to grain yield was equivalent only to that of the strain UFLA 02-86, with the mean values remaining below the values of the other inoculations (Table 3). In contrast, the selected strains, UFLA 02-100 and UFLA 02-127, exhibited yields higher than $2,800 \mathrm{~kg} \mathrm{ha}^{-1}$, which represents around three times the Brazilian mean value obtained in the 2015/16 crop season (Conab 2016). Furthermore, both strains provided a grain yield equivalent to that of the already recommended CIAT $899^{\mathrm{T}}$ strain and to the control with $80 \mathrm{~kg} \mathrm{ha}^{-1}$ of $\mathrm{N}$-urea. The good activity of these strains, just as that of UFLA 02-86 of $R$. etli bv. phaseoli, had already been mentioned in other studies, such as in Soares et al. (2006), who also obtained an increase in common bean yield in an Argissolo Vermelho distrófico (Typic Rhodustults - USDA classification) in Perdōes, Minas Gerais, with savings in the use of nitrogen fertilizer. In a Latossolo

Tabela 3. Mean values of number of nodules (NN), nodule dry mass (NDN), shoot dry mass (SDM), final stand (FS) and grain yield (GY) of common bean cv. Pérola, regarding to sources of $\mathrm{N}$.

\begin{tabular}{lccccc}
\hline Source of $N$ & NN & $\begin{array}{c}\text { NDN } \\
\left(\mathrm{mg} \mathrm{plant}^{-1}\right)\end{array}$ & $\begin{array}{c}\text { SDM } \\
\left(\mathrm{g} \mathrm{plant}^{-1}\right)\end{array}$ & $\begin{array}{c}\text { FS } \\
\left(10^{3} \text { plants ha- }^{-1}\right)\end{array}$ & $\begin{array}{c}\text { GY } \\
\left(\mathrm{kg} \mathrm{ha}^{-1}\right)\end{array}$ \\
\hline UFLA 02-100 & $29 \mathrm{a}$ & $22 \mathrm{a}$ & $9.39 \mathrm{a}$ & $246 \mathrm{a}$ & $2,883 \mathrm{~A}$ \\
UFLA 02-127 & $29 \mathrm{a}$ & $25 \mathrm{a}$ & $9.32 \mathrm{a}$ & $263 \mathrm{a}$ & $2,897 \mathrm{~A}$ \\
UFLA 02-86 & $36 \mathrm{a}$ & $27 \mathrm{a}$ & $10.92 \mathrm{a}$ & $246 \mathrm{a}$ & $2,620 \mathrm{~B}$ \\
CIAT 899 & $31 \mathrm{a}$ & $20 \mathrm{a}$ & $11.03 \mathrm{a}$ & $246 \mathrm{a}$ & $3,007 \mathrm{~A}$ \\
${ }^{*}$ CWN & $28 \mathrm{a}$ & $17 \mathrm{a}$ & $12.99 \mathrm{a}$ & $264 \mathrm{a}$ & $3,136 \mathrm{~A}$ \\
${ }^{* *}$ CwtN & $28 \mathrm{a}$ & $20 \mathrm{a}$ & $9.86 \mathrm{a}$ & $274 \mathrm{a}$ & $2,531 \mathrm{~B}$ \\
Means & 30 & 22 & 10.58 & 256 & 2,845 \\
\hline
\end{tabular}

Within each column, mean values followed by the same lowercase letters $(p<0.05)$ and uppercase letters $(p<0.10)$ belong to the same group, according to the Scott-Knott test. Control with no inoculation: ${ }^{\star} \mathrm{CwN}$-with fertilization $\left(80 \mathrm{~kg} \mathrm{ha}^{-1}\right.$ of $\mathrm{N}$-ureia), ${ }^{\star \star} \mathrm{Cw} \mathrm{N}$-without $\mathrm{N}$ fertilization. 
Vermelho eutroférrico (Eutric Acrudox - USDA classification) in Lavras, Minas Gerais, the strain UFLA 02-127 not only promoted a grain yield similar to that of the control fertilized with mineral N, but also exceeded CIAT $899^{\mathrm{T}}$ (Ferreira et al. 2009), reaffirming the symbiotic capacity of these strains with common bean. Based on these results and the results of this study, the UFLA 02-100 and UFLA 02-127 strains have potential for recommendation as commercial inoculants for common bean seeds, contributing to reduce the amount of crop fertilizer applied.

\section{ACKNOWLEDGMENTS}

We thank the Brazilian National Council for Scientific and Technological Development (CNPq), Coordination for the Improvement of Higher Level Personnel (CAPES), Research Support Foundation of the State of Minas Gerais(FAPEMIG), and the Brazilian Ministry of Agriculture, Livestock, and Food Supply (MAPA) for research productivity fellowships. We also thank Dr. Sérgio Henrique Godinho Silva, a specialist in pedology, for his valuable collaboration in soil classification.

\section{REFERENCES}

Brasil. Instrução normativa no 13 de 24 de março de 2011 anexo - protocolo oficial para avaliação da viabilidade e eficiência agronômica de cepas, inoculantes e tecnologias relacionados ao processo de fixação biológica do nitrogênio em leguminosas. Diário Oficial da Uniấo da República Federativa do Brasil, no 58 de 25 de março de 2011. (http://www.agricultura.gov.br/ assuntos/registro-de-produtos-e-estabelecimentos/arquivos-rpe/ IN132011 inoculprotocoloprocfixbiologicadoNemleguminosasa lterado3512.pdf). Accessed on 12/03/2014.

Conab (Companhia Nacional de Abastecimento) Acompanhamento de safra brasileira de grãos-Safra 2015/16 - N.12 - Décimo segundo levantamento. (http://www.conab.gov.br/OlalaCMS/uploads/ arquivos/16_09_06_09_03_20_boletim_12_setembro.pdf). Accessed on $15 / 12 / 2016$.

Ferreira, D.F. 2011. SISVAR: A computer statistical analysis system. Ciência e Agrotecnologia, 35: 1039-1042.

Ferreira, P.A.A.; Bomfeti, C.A.; Soares, B.L.; Moreira, F.M.S. 2012. Efficient nitrogen-fixing Rhizobium strains isolated from amazonian soils are highly tolerant to acidityand aluminium. World Journal of Microbiology and Biotechnology, 28: 1947-1959.
Ferreira, P.A.A.; Silva, M.A.P.; Cassetari, A.; Rufini, M.; Moreira, F.M.S.; Andrade, M.J.B. 2009. Inoculação com cepas de rizóbio na cultura do feijoeiro. Ciência Rural, 39: 2210-2212.

Figueiredo, M.A.; Oliveira, D.P.; Soares, B.L.; Morais, A.R.; Moreira, F.M.S.; Andrade, M.J.B. 2016. Nitrogen and molybdenum fertilization and inoculation of common bean with Rhizobium spp. in two oxisols. Acta Scientiarum. Agronomy, 38: 85-92.

Fonseca, G.G.; Oliveira, D.P.; Soares, B.L.; Ferreira, P.A.A.; Teixeira, C.M.; Martins, F.A.D.; Moreira, F.M.S.; Andrade, M.J.B. 2013.

Resposta de cultivares de feijoeiro-comum à inoculação das sementes com duas estirpes de rizóbio. Bioscience Journal, 29: 1778-1787.

Fred, E.B.; Waksman, S.A. 1928. Laboratory manual of General Microbiology: with special reference to the microorganisms of the soil. McGraw-Hill, New York, USA, 168p.

Moreira, F.M.S.; Siqueira, J.O. 2006. Microbiologia e bioquímica do solo. Lavras, Brasil, 729p.

Oliveira, D.P.; Figueiredo, M.A.; Soares, B.L.; Teixeira, O.H.S.; Martins, F.A.D.; Rufini, M.; Morais, A.R.; Moreira, F.M.S.; Andrade, M.J.B. 2016. Seed treatment with fungicides does not affect symbiosis between common bean (Phaseolus vulgaris L) and rhizobia. Agronomy Journal, 108: 1-8.

Oliveira-Longatti, S.M.O.; Marra, L.M.; Moreira, F.M.S. 2013. Evaluation of plant growth-promoting traits of Burkholderia and Rhizobium strains isolated from Amazon soils for their coinoculation in common bean. African Journal of Microbiology Research, 7: 948-959.

Rufini, M.; Ferreira, P.A.A.; Soares, B.L.; Oliveira, D.P.; Andrade, M.J.B. Moreira, F.M.S. 2011. Simbiose de bactérias fixadoras de nitrogênio com feijoeiro-comum em diferentes valores de $\mathrm{pH}$. Pesquisa Agropecuária Brasileira, 46: 81-88.

Soares, A.L.L.; Ferreira, P.A.A.; Pereira, J.P.A.R.; Vale, H.M.M.; Lima, A.S.; Andrade, M.J.B.; Moreira, F.M.S. 2006. Eficiência agronômica de rizóbios selecionados e diversidade de populaçóes nativas nodulíferas em Perdóes (MG) (II): feijoeiro. Revista Brasileira de Ciência do Solo, 30: 803-811.

Soares, B.L.; Ferreira, P.A.A.; Rufini, M.; Martins, F.A.D.; Oliveira, D.P.; Reis, R.P.; Andrade, M.J.B.; Moreira, F.M.S. 2016. Agronomic and economic efficiency of common-bean inoculation with rhizobia and mineral nitrogen fertilization. Revista Brasileira de Ciência do Solo, 40: 1-13.

Received: 15/12/2016

Accepted: 23/05/2017 